\title{
Analysis of surveying and legal problems in granting right-of-way and expropriation for the purpose of locating technical infrastructure
}

\author{
Anna Trembecka \\ AGH University of Science and Technology \\ Department of Engineering Surveying and Civil Engineering \\ 30 Mickiewicza St., 30-059 Krakow, Poland \\ e-mail: trembec@agh.edu.pl,
}

Received: 20 July 2015 / Accepted: 21 March 2016

\begin{abstract}
A condition which determines the location of technical infrastructure is an entrepreneur holding the right to use the property for construction purposes. Currently, there are parallel separate legal forms allowing the use of a real property for the purpose of locating transmission lines, i.e. transmission easement (right-of-way) established under the civil law and expropriation by limiting the rights to a property under the administrative law.

The aim of the study is to compare these forms conferring the right to use real properties and to analyze the related surveying and legal problems occurring in practice. The research thesis of the article is ascertainment that the current legal provisions for establishing legal titles to a property in order to locate transmission lines need to be amended.

The conducted study regarded legal conditions, extent of expropriation and granting rightof-way in the city of Krakow, as well as the problems associated with the ambiguous wording of the legal regulations. Part of the research was devoted to the form of rights to land in order to carry out similar projects in some European countries (France, Czech Republic, Germany, Sweden). The justification for the analysis of these issues is dictated by the scale of practical use of the aforementioned forms of rights to land in order to locate technical infrastructure. Over the period of 2011-2014, 651 agreements were concluded on granting transmission right-of-way for 967 cadastral parcels owned by the city of Krakow, and 105 expropriation decisions were issued, limiting the use of real properties in Krakow.
\end{abstract}

Keywords: real property, transmission easement, expropriation

\section{Introduction}

The characteristic feature of the investments relating to the location of public utilities and technical infrastructure is that they run linearly through many plots of land, occupying part of these real properties. Their location is not random, but it is determined by economic and social needs. A condition which determines the location 
of technical infrastructure is an entrepreneur holding the right to use the property for construction purposes. The legal title may result from ownership, perpetual usufruct, administration, limited property rights or contractual relationship providing rights to carry out construction works.

As regards public transmission facilities, there is also a possibility of expropriation by limiting rights to use a property under the administrative law. In this case, the expropriation involves allowing for the execution and placement of drainage pipes, lines and other equipment used for transmission or distribution of liquids, steam, gas, electricity, for public communications and signaling, as well as other underground, ground-based or overhead facilities and equipment necessary to use these lines.

Expropriation is implemented if public purposes can not be executed in any other way than by limiting property rights, and those rights cannot be acquired by way of an agreement. Construction and maintenance of the aforementioned utilities and technical infrastructure is one of the public purposes set out in article 6 of the Act (Act, 1997).

Expropriation by limiting the rights to use a property, as a particular type of expropriation, was introduced in Poland by the Act of 12 March 1958 on the principles and procedures of real estate expropriation, and it is currently governed by article 124 of the Act (Act, 1997).

As of 3 August 2008, pursuant to the Act (Act, 2008), a new limited property right was introduced to the Civil Code - right-of-way. It consists in that the real property may be encumbered with the right for the benefit of the entity who intends to construct, or owns, transmission facilities referred to in article $49 \S 1$ (Act, 1964) to use it within a given scope, in accordance with the intended purpose of these devices (art. $305^{1}$ of the Civil Code).

The result of these regulations are two forms of rights to land to locate transmission facilities which are binding in the legal system, which induces to search for relationships between them. Limitation of property rights (expropriation) is frequently treated as transmission right-of-way. It is, however, incorrect, as these forms exhibit a number of peculiarities in terms of procedure and conditions for the establishment. Perhaps in the future, article 124 of the Act (Act, 1997) should serve the purpose of establishing transmission rights-of-way under the administrative procedure.

The aim of the study is to analyze surveying and legal issues related to the establishment of right-of-way and expropriation for the purposes of locating transmission facilities, as well as to identify the relationships between these forms of rights to land.

The source material includes legal provisions, literature and the results of the research on expropriation by limiting property rights to real estate and granting rightof-way in order to locate technical infrastructure over the period of 2011-2014 in the city of Krakow. 


\section{The legal status of transmission facilities}

The legal status of transmission facilities is regulated by article 49 of the Civil Code. According to this provision, the equipment for supplying or removing liquids, steam, gas, electricity, and others, are not elements of the real property if they are part of the company.

This equipment, when connected to the network owned by the company, are no longer part of the property and they become self-contained movable property, which may be subject to separate ownership rights and separate transaction. This is an exception to the rule contained in article 48 of the Civil Code, according to which building structures and other facilities permanently attached to the land are the component parts of this land. Therefore, if such facilities are not part of the company, they constitute components of the land and, consequently, property of the land owner. Therefore, components of land will include, for example, water pipes supplying water to the building from a well located on the plot of land.

As soon as the facilities are connected, the company can use them, but this does not automatically result in the acquisition of the ownership rights to them, or any other rights to these devices. A person who incurred the costs of their construction, and is the beneficial owner, may request that the entrepreneur who connected these facilities to their network, acquired property rights for an appropriate consideration, unless otherwise provided by the parties in the agreement. Also the entrepreneur may request the transfer of ownership rights to these facilities. In the concluded agreement, the parties may stipulate this disposal to be free of charge.

Acquisition of ownership rights to transmission facilities may be based on the agreement. If, however, there is no consensus, there is a possibility of initiating court proceedings.

Connections have separate legal status. Connections are understood as devices used to connect to the network of internal installations. The function of the connectors is connecting the internal system and the network. In its resolution (Resolution, 2006), the Supreme Court took the view that a connection is an independent movable item, if connected to the network.

\section{Comparative analysis of the process of establishing transmission right-of-way and expropriation by limiting property rights}

Investor of transmission facilities may acquire the right to use a real property for construction purposes under the civil law by concluding an appropriate agreement with the owner or perpetual user, transferring such rights to the investor (sale, exchange, donation), or establishing other law encumbering ownership rights or perpetual usufruct (e.g. use, lease, easement, transmission right-of-way, lending).

In addition to these legal forms, there is a possibility of the administrative law interfering with the rights of the owner or perpetual usufructuary by a decision 
authorizing the execution and conduct of a public technical infrastructure network or facilities on this real estate.

The most commonly used in practice forms of rights to land for locating transmission facilities include as follows:

- right-of-way established under the civil law, introduced to the Civil Code in 2008,

- expropriation by limiting property rights under the administrative proceedings.

Right-of-way means that the entrepreneur may use a servient real estate within a given scope, in accordance with the intended purpose of the transmission facilities. The resulting right includes construction of facilities, maintenance and troubleshooting.

Limitation of rights to a real property, which is a special kind of expropriation, is a temporary deprivation of the exercise of rights in rem, or a temporarily indefinite deprivation of certain rights, without deprivation of the right itself (Wolanin, 2009). This limitation applies to the exercise of the ownership right or right of perpetual usufruct, and it may also concern properties with unclear legal status.

The conditions of expropriation are as follows:

- no consent of the owners or perpetual users to take over a property to locate technical infrastructure;

- public nature of the technical infrastructure resulting from the findings of the zoning plan or from the decision on the location of public investment;

- inability to carry out public purposes otherwise.

Anyone who performs a public purpose, and not just the State Treasury or a local government unit, can be the entity authorized to request for limitation on the use of a property in order to locate a network of technical infrastructure (Trembecka, 2015). The entity, who was issued with a decision, is granted a permanent title to the real property under the administrative law, which allows to:

- locate transmission networks and facilities,

- use the property in a continuous manner by locating transmission networks and facilities there,

- use the real property incidentally to implement maintenance and emergency repairs.

The analyzed forms constitute a permanent title to a real property, which is important, as locating a network involves trespassing for the time of construction and leaving facilities in the ground, access for repair or maintenance purposes. These rights are also entered in the land and mortgage register.

Given the dominant role of these forms of property disposal in investment processes related to transmission facilities, their characteristic features were analyzed, with the essential differences between them being identified. The results of the analysis have been presented in Table 1. 
Table 1. Characteristic features of the rights to land, used to locate transmission facilities

\begin{tabular}{|c|c|c|}
\hline Criterion & Expropriation by limiting rights to land & Right-of-way \\
\hline $\begin{array}{l}\text { Procedure and } \\
\text { form }\end{array}$ & $\begin{array}{l}\text { administrative proceedings } \\
\text { administrative decision limiting the } \\
\text { manner of the use of a property by } \\
\text { allowing to locate transmission facilities }\end{array}$ & $\begin{array}{l}\text { civil proceedings } \\
\text { agreement, court's decision, court } \\
\text { settlement, acquisitive prescription }\end{array}$ \\
\hline Legal bases & $\begin{array}{l}\text { art. } 124 \text { of the Real Estate Management } \\
\text { Act }\end{array}$ & art. $305^{1}-305^{4}$ of the Civil Code \\
\hline The purpose & For the planned transmission facilities & $\begin{array}{l}\text { For the planned and the existing } \\
\text { transmission facilities }\end{array}$ \\
\hline $\begin{array}{l}\text { The subject of } \\
\text { encumbrance }\end{array}$ & $\begin{array}{l}\text { Land, building or dwelling unit, the } \\
\text { right of perpetual usufruct }\end{array}$ & Land, building or dwelling unit \\
\hline $\begin{array}{l}\text { The authorized } \\
\text { entity }\end{array}$ & $\begin{array}{l}\text { Legal persons, natural persons, entities } \\
\text { who are not legal persons and who } \\
\text { implement technical infrastructure as } \\
\text { a public purpose }\end{array}$ & $\begin{array}{l}\text { An entrepreneur who intends to } \\
\text { construct transmission facilities or who } \\
\text { owns transmission facilities }\end{array}$ \\
\hline $\begin{array}{l}\text { Subject of } \\
\text { authorization }\end{array}$ & $\begin{array}{l}\text { The investor is authorized to make } \\
\text { use of the property in order to build } \\
\text { technical infrastructure and to leave it } \\
\text { there. The property owner is obligated } \\
\text { to make the property accessible for } \\
\text { maintenance and troubleshooting } \\
\text { purposes. }\end{array}$ & $\begin{array}{l}\text { The entrepreneur is authorized to use } \\
\text { the property in order to locate, maintain } \\
\text { and utilize transmission facilities, } \\
\text { to carry out inspection procedures, } \\
\text { maintenance control, troubleshooting. } \\
\text { The owner may commit to leave an } \\
\text { easement strip as an undeveloped area, } \\
\text { free from planting trees or shrubs. }\end{array}$ \\
\hline $\begin{array}{l}\text { Territorial } \\
\text { limitation }\end{array}$ & $\begin{array}{l}\text { According to the local land-use plan } \\
\text { or decision on the location of a public } \\
\text { purpose, } \\
\text { the expropriation decision should } \\
\text { specify the area for the construction of } \\
\text { technical infrastructure which is subject } \\
\text { to limitation }\end{array}$ & $\begin{array}{l}\text { According to settlements of contracting } \\
\text { parties or court decision, with regard } \\
\text { to the course of the existing networks } \\
\text { (in the case of regulating "legacy") } \\
\text { or networks which are planned to be } \\
\text { built, transmission facilities and the } \\
\text { area on which right-of-way is to be } \\
\text { implemented must be marked on the } \\
\text { map, drawn up according to the rules } \\
\text { for designating real estate in land and } \\
\text { mortgage registers.. }\end{array}$ \\
\hline $\begin{array}{l}\text { Compensation } \\
\text { Consideration }\end{array}$ & $\begin{array}{l}\text { Compensation is determined in separate } \\
\text { administrative proceedings, after the } \\
\text { investment has been implemented and } \\
\text { having ascertained that it is not possible } \\
\text { to restore a real property to its original } \\
\text { state. }\end{array}$ & $\begin{array}{l}\text { Consideration is determined in } \\
\text { agreement or judicial decision (except } \\
\text { for acquisitive prescription). This may } \\
\text { be a one-off or periodic benefit. The } \\
\text { easement may be determined free of } \\
\text { charge. }\end{array}$ \\
\hline
\end{tabular}

Source: own study 
In the event of expropriation, compensation shall be determined in accordance with the regulations laid down in the Act of 21 August on the Real Estate Management, and in the Regulation of the Council of Ministers of 21 September 2004 on the valuation of real estate and preparing appraisal.

The compensation should correspond to the value of the damage. While being determined, the following should be considered in particular, in accordance with section 43 (Regulation, 2004):

1) development status of the real property as of the issuance date of the decision on limiting the use of the real property, and the development status of the real property as of the date of the completion of the activities justifying the issuance of that decision; 2) loss of benefits in the period from the date of the decision being issued until the completion of the activities justifying its issuance.

If, as a result of locating technical infrastructure, the value of the real property reduces, the compensation shall be increased by an amount corresponding to this reduction.

In the case of transmission right-of-way, for the determination of consideration, the standard of appraisers can apply: "Specifying the value of right-of-way and consideration for non-contractual use of the property by transmission entrepreneurs".

Analysis of the methodology for determining the value of a limited property right, which right-of-way belongs to, have been presented in the article "Compensation and consideration in establishing right-of-way" (Konieczny, 2012). The author of the study identifies the difference between consideration and compensation associated with the law governing the issue of right-of-way. Consideration corresponds to the extent of using the occupied area, while compensation applies to the damage related to construction or consequences of recovery of transmission facilities failure.

Regulations, which are similar to the right-of-way, exist in other European countries as well. For example, in France the location of technical infrastructure is based on "servitude". However, there are different legislative rules for their establishing. Article 649 of the French Civil Code distinguishes between easement for public utilities and for private utilities. For the public purposes (which includes e.g. distribution of water, gas, electricity, etc.), in the absence of the consent of the owners, the easement is established in administrative proceedings. Its beneficiaries may include, e.g. public companies, concessionaires of public services. Establishment of easement gives the right to compensation.

In the Czech Republic, the location of technical infrastructure must be preceded by negotiations with land owners in order to conclude a lease agreement or to establish easement. If the agreement is not concluded, the expropriating authority is entitled to decide on the establishment of easement for the transmission company for a consideration corresponding to the market standards in a given area at a given time. Limitation of property rights of private land owners cannot go beyond further than it is necessary to locate public technical network. 
In Germany, on the other hand, the location of public technical infrastructure requires easement to be established, where the easement on state-owned land is free, $b$ subject to certain (not very high) fees for issuing a relevant permit or a building permit, relating to individual installations. Easement on private land requires compensation in a reasonable amount to be paid to the land owner.

The installation of infrastructure by a transmission company must be carried out in accordance with applicable technical and environmental regulations, and all construction works on the easement must be made in such a way that they breach publicly or privately owned property as little as possible.

In Sweden, owners of the technical network protect their rights to land by establishing easement or transmission right-of-way. Agreements regarding easement may be concluded only for a limited period, i.e. for no longer than 25 years in urban areas and up to 50 years in the non-urban areas. Only right-of-way may be concluded for an indefinite period. In the case when some of the land owners do not agree to the terms of the agreement or demand excessive compensation, the network owner may request for an expropriation (or, if possible, for an alternative solution regarding network location). Issuing decisions on easement for networks belongs to the administrative body, i.e. Head Office of Geodesy. There is a possibility to appeal to court against such a decision.

The rules governing the issues of expropriation and compensation based on the regulations in Poland and other countries have been presented in (Źróbek and Walacik, 2008).

The article (Walacik, 2012) presents the rules of expropriation in Norway. The paper (Walacik et al., 2013) contains a comparative analysis of the procedures for real estate valuation in Poland, Slovakia and the United States.

With regard to the compensation for expropriation, Great Britain exhibits significant differences in the regulation, when compared to those in our country (Fisher, 2010). Compensation for the expropriated property also includes nonmaterial damage resulting from discomfort and inconvenience of expropriation as well as costs of moving or adapting substitute premises. In many countries (Finland, Norway. Hungary, Canada), the compensation is increased by the lost benefits.

\section{Results of the study of the process of expropriation by limiting rights to a property and establishing right-of-way on the example of the city of Krakow}

In the years 2011-2014, in the city of Krakow, 105 decisions on expropriation by limiting rights to a property were issued for the purpose of locating networks and technical infrastructure. Table 2 shows the number of expropriation decisions for each transmission device, divided by individual years. 
Table 2. Expropriations by limiting rights to a property in the city of Krakow

\begin{tabular}{|c|c|c|c|c|}
\hline \multirow{2}{*}{ Year } & \multicolumn{4}{|c|}{ Number of expropriation decisions } \\
\cline { 2 - 5 } & Water supply & $\begin{array}{c}\text { Rain water } \\
\text { drainage networks }\end{array}$ & Heating networks & $\begin{array}{c}\text { Telecommunication } \\
\text { networks }\end{array}$ \\
\hline $2011-2012$ & - & - & - & - \\
\hline 2013 & 19 & 15 & - & - \\
\hline 2014 & 33 & 36 & 1 & 1 \\
\hline Total & 52 & 51 & 1 & 1 \\
\hline
\end{tabular}

Source: own study

Expropriation decisions were issued due to the negative outcome of negotiations with property owners on making them accessible for investments, including granting right-of-way. The entities applying for the establishment of expropriation (representatives of transmission companies) did not attempt to establish rights-ofway as limited property rights by way of court proceedings. No other negotiations were undertaken on other forms of land acquisition either, e.g. by way of a purchase.

The studies regarding the process of granting right-of-way to transmission companies on the land owned by the city of Krakow revealed that, in the analyzed period, 651 agreements covering 967 cadastral parcels were concluded. The total consideration amounted to over 48 million PLN (Table 3).

Table 3. Granting right-of-way for transmission companies on the land owned by the city of Krakow

\begin{tabular}{|c|c|c|c|}
\hline Year & Number of agreements & $\begin{array}{c}\text { Number of plots covered } \\
\text { by the agreements }\end{array}$ & $\begin{array}{c}\text { Consideration for granting } \\
\text { rights-of-way [PLN] }\end{array}$ \\
\hline 2011 & 64 & 111 & $1,049,189$ \\
\hline 2012 & 158 & 220 & $5,290,287$ \\
\hline 2013 & 299 & 360 & $30,767,724$ \\
\hline 2014 & 130 & 276 & $11,283,317$ \\
\hline Total & 651 & 967 & $48,390,517$ \\
\hline
\end{tabular}

Source: own study

Right-of-way has been widely used to control the "legacy", i.e. the cases where networks were built in the past without an appropriate legal title to the land. This is confirmed by a detailed analysis of the process of establishing transmission right-ofway on the land owned by the city of Krakow for the benefit of the Municipal Water and Sewerage Public Company, performed by the author and expanding it for the year 2014. The previous studies were described in (Trembecka, 2014). 
Table 4. Granting rights-of-way for the Municipal Water and Sewage Public Company on the land owned by the city of Krakow

\begin{tabular}{|c|c|c|c|c|c|c|c|c|}
\hline \multirow[b]{2}{*}{ 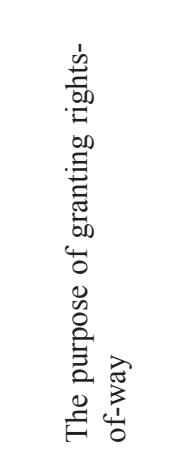 } & \multicolumn{2}{|c|}{$2009-2011$ year } & \multicolumn{2}{|c|}{2012 year } & \multicolumn{2}{|c|}{2013 year } & \multicolumn{2}{|c|}{2014 year } \\
\hline & 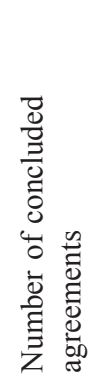 & 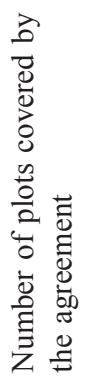 & 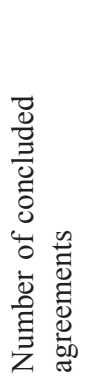 & 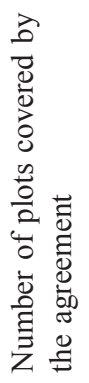 & 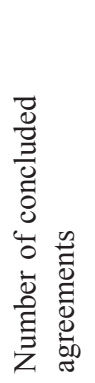 & 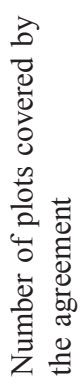 & 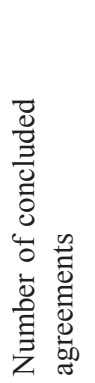 & 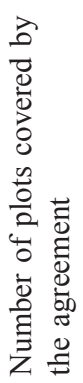 \\
\hline $\begin{array}{l}\text { Building new } \\
\text { networks }\end{array}$ & 95 & 99 & 15 & 19 & 8 & 10 & 8 & 11 \\
\hline $\begin{array}{l}\text { Regulating } \\
\text { the "legacy" }\end{array}$ & & & 90 & 99 & 228 & 230 & 51 & 53 \\
\hline Total & 95 & 99 & 105 & 118 & 236 & 240 & 59 & 64 \\
\hline
\end{tabular}

Source: own study

In the period of 2009-2011, the Municipality of Krakow established transmission rights-of-way on 99 plots of land, concluding 95 agreements, but only for the construction of new water supply networks (Table 4).

The process of regulating the so-called "legacy" began in 2012. Until 2014, 495 agreements on granting transmission rights-of-way were concluded with respect to 521 plots, of which 369 agreements covering 382 plots related to the existing networks, while 126 agreements covering 139 plots concerned networks which were planned to be built.

\section{Surveying and legal issues related to the process of establishing legal titles to real properties in order to locate transmission facilities}

In the course of establishing legal titles to real properties in order to locate transmission facilities, surveying and legal problems occur. One of them is the question of the possibility of establishing right-of-way for the right of perpetual usufruct. The case law of the civil courts is not uniform in this respect. Pursuant to art. $305^{1}$ of the Civil Code, right-of-way means that the entrepreneur may use a servient real estate within a given scope, in accordance with the intended purpose of the transmission facilities. The resulting right includes construction of facilities, maintenance and troubleshooting.

Perpetual usufruct is a legal form of utilizing a real property owned by the State Treasury or local government units. It is a right in rem (intermediate between ownership 
and limited property rights) which is relatively permanent, specific, temporary and for a consideration. Perpetual user (within the limits laid down by the laws and rules of social interaction and by the agreement on transfer of land in perpetual usufruct) may use the land exclusively of others, and dispose of their right.

The right of perpetual usufruct involves some charges, including:

- the first payment in the amount of $15-25 \%$ of the property value,

- annual fees depending on the purpose of letting the land for perpetual usufruct.

In accordance with the provisions of the Supreme Court of 15 October 2008 (Provision, 2008), the entitlement of a usufructuary to dispose of their rights includes the ability to encumber their right with easement. Despite the fact that the judgment concerned the land easement, the view of the Supreme Court in the doctrine was adopted for the right-of-way. Also, the literature presents a standing that there is a possibility of establishing right-of-way on the right of perpetual usufruct. If a usufructuary is entitled to use the land exclusively of others, they may establish easement, even without the consent of the property owner. (Balwicka-Szczyrba, 2015).

A contrasting view is presented in the judgment of the Supreme Court of 28 March 2014 (Judgment, 2014) which states that right-of-way is to encumber a real property, and not the right of perpetual usufruct established there, and it must ensure a stable title for the entrepreneur to use transmission facilities. Allowing for the establishment of right-of-way for perpetual usufruct rights - as temporary right - could cause problems in the event of termination of this right. Then the question arises related to the transmission facilities and a possible subsequent settlement for their location with the owner of the property. Given the public interest represented by a transmission entrepreneur, it is necessary to preserve the stability of the legal relationship, which is why, in the opinion of the Supreme Court, the right-of-way should be established in relation to property owners.

This thesis seems to be confirmed by the wording of the regulations governing the right-of-way. In article $305^{2}$ of the Civil Code, a perpetual user is not appointed as a party of transmission easement by the legislature, in contrast to article 124 of the Act (Act, 1997) which concerns the expropriation decisions limiting ownership rights to a property in order to locate transmission facilities there.

However, the issues related to the right-of-way encumbering ownership rights to a property in perpetual usufruct are not devoid of doubts and controversy, either (Nowak, 2015). Granting right-of-way by the property owner may limit the possibility to use this property by the perpetual user, and sometimes even hinder the user from achieving their objectives related to letting this property for perpetual usufruct. Such a situation may result in possible claims for damages against the property owner. A separate issue in these cases, is the necessity to update the annual fees based on the new value of the property.

Another problem concerns the possibility of establishing titles authorizing the location of transmission facilities in relation to real properties seized in the course of enforcement proceedings. According to the Code of Civil Procedure, encumbrance of a real property by the debtor after its seizure is null and void. Therefore, there is no 
possibility of establishing the transmission right-of-way on the property seized in the course of enforcement proceedings through legal action (agreement). However, there is a possibility to encumber the property seized in the course of enforcement proceedings with right-of-way through a court decision. The court practice in this respect is not uniform, though. There are cases of rejecting the application or suspending it until enforcement proceedings have finished. The establishment of transmission right-ofway through court proceedings is possible, because the change of the owner does not affect the scope of the easement and the amount of consideration (Matys, 2015). There are no obstacles regarding expropriation of the property seized in the course of enforcement proceedings, either.

Yet another problem is the issue of a strip of land to locate transmission facilities. The agreement granting right-of-way may include a provision regarding a strip of land based on the definitions contained in the standards of professional property valuers (national standard for specialist valuation "Specifying the value of rightof-way and consideration for non-contractual use of the property by transmission entrepreneurs"). In accordance with the definition contained therein, a strip of land for transmission easement covers utility belt, and it also may include, depending on the circumstances, the impact zone of the device. The utilization belt is understood as the area of a part of the property required to use transmission facilities by the entrepreneur. The surface of the belt should be defined by the entrepreneur, according to the actual needs.

However, in the event of expropriation, the provisions of the Land Management Act do not specify precisely the scope of the limitation on using the property - it is not clear whether it can also include the protective belt of transmission facilities. Expropriation decision should specify the subject of temporary seizure and its territorial extent, together with the determination of its intended use in the zoning plan or the conditions resulting from the decision on establishing the location of public purpose investment. Doubts arise, however, regarding possible limitations on the right also in relation to the impact zone of the device (the protection zone). In the analyzed expropriation decisions, despite the applicant's request, the area covered by the authorization to locate the network and technical infrastructure did not take into account the impact zone of transmission facilities.

Geodetic determination of the scope of the restriction on the rights is a significant issue. The legislator specified neither the content of the investor's application nor the surveying documents which should define the extent of the servient real estate and constitute an annex both to the administrative decision pursuant to Art. 124 of the Act, as well as to the agreement establishing the right-of-way. In practice, most commonly, these activities are performed by surveyors by marking the course of the planned network on the cadastral map. However, these activities should be strictly agreed upon with network designers and investors.

Another problem concerns the term of temporary seizure of a property by the transmission company in the event of expropriation. Article 124 of the Act (Act, 1997) does not provide for anything in this regard. However, the doctrine (Jaworski 
et al., 2009) points out to the need to define a term in the decision, for which the authorization to occupy the property is granted. In practice, this term is difficult to predict, especially in the case of linear investments of large range, carried out in stages. Therefore, a precise definition is required in the Act which concerns the problem of a mandatory specification in the expropriation decision of the term in which the real property covered by the authorization to carry out technical infrastructure will be occupied.

Under the provisions of article 124, paragraph 5 of the Act (Act, 1997), if the location or course of cables, lines, or equipment, prevents the owner or perpetual user from further utilization of the property as it was utilized, or in a manner consistent with its current purpose, the owner or the usufructuary may require that the governor, the person implementing the task of the government administration, or the person applying for a permit, purchased by means of an agreement the ownership or perpetual usufruct rights to that real estate for the benefit of the State Treasury. The provision stipulates that the acquisition may be effected only for the benefit of the Treasury. If, however, the infrastructure investment was implemented by the municipality as its own statutory task, a doubt is raised over the commitment of the State Treasury to purchase it.

Yet another problem concerns the possibility of locating the infrastructure network on the property with the unclear legal status. Pursuant to article 113 paragraph 6 of the Act (Act, 1997), a property with unclear legal status is understood as the property for which, due to the lack of land and mortgage register, a collection of documents, or other documents, persons who are entitled to the rights in rem can not be determined. This also applies to a situation when the owner or usufructuary of the property is deceased, and the inheritance proceedings were not carried out or were not completed. In such situations, it is not possible to grant right-of-way. Expropriation is acceptable, but with proper procedures provided for a property with unclear legal status. Then the authority conducting the proceedings is obliged to make public statement on their intention to expropriate. If, within a stated time limit, no person was identified who has rights in rem to that real estate, the governor issues a decision on expropriation.

The scope of applying the provisions on expropriation for the purposes of technical infrastructure (art. 124 (Act, 1997)) is much narrower in relation to the provisions on the transmission right-of-way. It covers the stage before the implementation of transmission investment and regards only public purposes. However, after the completion of a public investment, solely the provisions giving rise to the claims of the owner and the transmission entrepreneur will apply.

On the other hand, the contractual stage gives freedom to shape the rights to use the land - from obligatory consents to transmission easement. The establishment of rights-of-way is possible only for the entrepreneur who owns facilities for feeding or removing liquids, steam, gas, electricity and other similar installations, or who intends to build such facilities. This means that right-of-way may apply to both 
factual circumstances when the transmission facilities already exist, but also when the entrepreneur is only going to build these facilities in the future. This allows both to regulate the so-called "legacy", and protects the legal interests of entrepreneurs already during the planning stage (Bieniek, 2008). The research confirms that it allowed to regulate the rights of the Municipal Water and Sewerage Public Company (MPWiK SA) regarding 369 cadastral parcels, seized for the technical infrastructure in the past.

The entrepreneur may use the property as soon as the agreement on the establishment of right-of-way has been signed. However, in the event of expropriation, limitation on the right is binding following the date of the decision being final. To meet the investors' needs, there is article 122 paragraph 1a of the Act (Act, 1997), according to which in the cases specified in article 108 of the Administrative Code or in the cases justified by important economic interests, the governor, at the request of the entity who will carry out a public purpose, shall, by means of a decision, permit the immediate seizure of the property after issuing the decision on limiting the rights. The decision on immediate seizure of the property shall be immediately enforceable.

\section{Summary and conclusion}

1. The article presents a comparative analysis of basic legal forms allowing the use of a property to locate technical network and technical infrastructure, i.e. right-ofway and expropriation by limiting the use of the property.

2. Limiting the use of a property under the administrative law is a special case of expropriation, and therefore it can only refer to public investments. This procedure can be used exclusively for the planned investments regarding transmission facilities; in contrast to the right-of-way, it may not be used for the regularization of the "legacies", where the facilities have already been built.

3. One of the most significant differences in these two forms is the problem of compensation. Conclusion of the transmission right-of-way agreement allows to settle the amount of consideration under the civil law, already at the time of its conclusion. In the case of expropriation, compensation is determined in a separate administrative decision, often in distant future, after the investment has been carried out, and having determined that it is not possible to restore the property to its original state.

4. The studies performed in relation to the real properties owned by the city of Krakow have revealed that right-of-way is widely applied in practice. In the period of 2011-2014, 651 agreements were concluded, which covered 967 cadastral parcels owned by the city of Krakow. Detailed analysis of one of the city's transmission companies, the Municipal Water and Sewerage Public Company (MPWiK SA), proved that 382 cadastral parcels had the "legacy" regulated by being granted the right-of-way. 
5. In the same period, 105 expropriation decision were issued, which limited the use of real estates, mainly due to the planned location of water supply installations and public rainwater drainage systems.

6. When analyzing the issues, geodetic and legal problems, as well as interpretative doubts, were pointed out, which make it difficult in practice to determine the rights to a real property in order to locate transmission facilities. This confirms the research thesis regarding the need to change the legislation to precisely specify the rules of conduct, which would contribute to more efficient procedures and a unified settlement of cases.

7. In the light of the right-of-way being introduced to the Civil Code in 2008 as a limited property right, it should be considered whether it is justifiable to maintain in the legal system expropriation by limiting rights to a property under administrative procedure in order to locate technical infrastructure. It is in fact a significant interference of public authorities in the sphere of private ownership rights.

\section{Acknowledgment}

I would like to give my thanks to Prof. Elżbieta Bielecka, PhD.Eng. for her really valuable comments and help. Krakow City Hall - City Treasury Department for the assistance in obtaining data on expropriation by limiting property rights to real estate and granting right-of-way in order to locate technical infrastructure AGH University of Science and Technology, Department of Engineering Surveying and Civil Engineering for financing the works on the article. The research work was carried out within the statutory research of the Department of Surveying Engineering and Construction No. 11.11.150. 005.

\section{References}

Balwicka-Szczyrba, M. ( 2015). The use of a property by transmission companies - owners of transmission facilitie., Warsaw: Wolters Kluwer: Business.

Bieniek, G. (2008). Transmission facilities. Legal Issues. Warsaw: LexisNexis.

Council of Ministers. (2004). Decree of September 21, 2004 The Regulation on the property valuation and the preparation of an appraisal study. Warsaw: Journal of Laws on No. 207, entry2109

Fisher, G. (2010). Compulsory Purchase Compensation: A Glimpse of Eminent Domain in the United Kingdom. Right of Way Magazine, no 9-10, pp 26.

Gdesz, M. and Trembecka A. (2013). Public real estate law. Katowice:.Gall.

Jaworski, J., Prusaczyk, A., Tułodziecki, A. and Wolanin, M. (2009). Commentary to the Real Estate Management Act. Warsaw: C.H. Beck.

Konieczny, D. (2012). Compensation and consideration in establishing right-of-way. TNN Studies and Materials. Vol. 20, No. 2, 131-140.

Matys, L. (2015). Establishment of right-of-way on a property seized by enforcement procedures. Real Estate. C.H. Beck. 22-24. 
Nowak, M. J. (2015). Right-of-way - ownership, perpetual usufruct. Real Estate. C.H. Beck, No. 8, 1922.

Polish Parliament (1960). The Act of June 14, 1960 The Code of Administrative Procedure. Warsaw: Journal of Laws on 2013 entry 267.

Polish Parliament (1964). The Act of April 23, 1964 The Civil Code. Warsaw: Journal of Laws on 2014 entry 121.

Polish Parliament (1964). The Act of November 17, 1964 The Code of Civil Procedure. Warsaw: Journal of Laws on 2014 entry 101.

Polish Parliament (1997). The Act of August 21, 1997 The Act on real estate management. Warsaw: Journal of Laws on 2015 entry 782.

Polish Parliament (2008). The Act of May 30, 2008 The Act on the amendments to the Civil Code and some other laws. Warsaw: Journal of Laws on 2008 No. 116 entry 731.

Supreme Court (2006). Resolution of March 8, 2006 Ref. No. III CZP 105/05. Warsaw: OSN 2006, No. 10 , entry 159.

Supreme Court (2008). Resolution of October 15, 2008 Ref. No. I CSK 135/08, Legalis.

Supreme Court (2014). Judgment of March, 2014 Ref. No. III CSK 174/13, LEX.

Trembecka, A. (2014). Forms of disposal of a real property for the construction of technical infrastructure. Infrastructure and ecology of rural areas. Polish Academy of Sciences in Krakow, 481-492.

Trembecka, A., 2015, Real estate management. Theory and practice. Krakow: AGH Publishing House.

Wolanin, M. (2009). Expropriation as a legal instrument for enlarging public ownership of real estate. Part 1. Real Estate C.H. Beck, No. 7, 2-8.

Walacik, M. (2012). Selected principles and procedures for the acquisition of property for the implementation of road projects in Norway. Newsletter of the Association of Valuers of the Wielkopolska Region, no. 4.

Walacik, M., Richard, G. and Adamuscin, A. (2013). Valuation systems in Poland, Slovakia and The United Kingdom - Comparative study. Real Estate Management and valuation, vol. 21, no. 4, 7586. DOI: $10.2478 /$ remav-2013-0039.

Źróbek, S. and Walacik, M. (2008). Comparative analysis of selected issues of real estate expropriation in Poland and abroad. Surveying Overview, No. 12, 4-9.

https://www.legifrance.gouv.fr/affichCode.do?cidTexte=LEGITEXT000006070721

http://www.twobirds.com/en/news/articles/2012/intcomms-oct12

http://www.scandinavianlaw.se/pdf/47-24.pdf 
